\title{
Mathematical modeling for ethanol, methanol and acetaldehyde generation through Mexican carignane grape (Vitis vinifera) vinification process
}

\author{
Modelación matemática para la generación de etanol, metanol y acetaldeído durante el proceso \\ de vinificación de uva Mexicana carignane (Vitis vinifera)
}

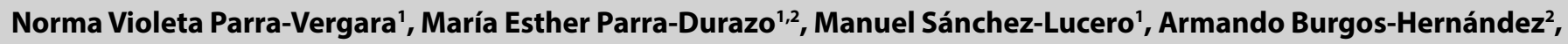
Octavio Cota-Arriola ${ }^{3}$, Ofelia Rouzaud-Sandez ${ }^{2}$, Carmen María López-Saiz ${ }^{3 *}$

Departamento de Investigación y Posgrado en Alimentos, Universidad de Sonora, Apartado Postal 1658, Hermosillo, Sonora 83000, México

2 Instituto del Manejo, Conservación y Procesamiento de Alimentos, Hermosillo, Sonora 83140, México

${ }^{3}$ Environmental Engineering Program, Sonora State University, Hermosillo, Sonora, México.
\end{abstract}

\section{ABSTRACT}

Wine is a worldwide known beverage, and even though its consumption has been associated with the reduction of heart diseases and the extent of lifespan, it also has compounds that might cause adverse effects on human health such as methanol and acetaldehyde. The aim of this study was to determine the effect of time, temperature, and pectic enzymes over wine methanol and acetaldehyde concentrations during vinification. Three temperatures $(20,30$, and $\left.35^{\circ} \mathrm{C}\right)$ and three pectic enzyme concentrations $(0,9$, and $18 \mu \mathrm{L} / \mathrm{Kg}$ ) were tested, allowing fermentation to stop due to sugar depletion. Both methanol and acetaldehyde were quantified throughout the fermentation process. Temperature reduced methanol production, observing the lowest methanol concentration ( $53.543 \pm 3.267 \mathrm{mg} / 100 \mathrm{~mL}$ of wine) at $35^{\circ} \mathrm{C}$ in the absence of pectic enzyme. Acetaldehyde was not affected by these variables. Alcohol, methanol, and acetaldehyde concentrations were adjusted to mathematical models with high correlations.

Keywords. Toxic compounds, wine, mathematical modeling, fermentation.

\section{RESUMEN}

El vino es una bebida conocida a nivel mundial, y aun cuando su consumo ha sido asociado a la reducción de enfermedades cardiacas y la extensión de la esperanza de vida, también posee compuestos que pueden tener efectos adversos a la salud humana tales como el metanol y el acetaldehído. El objetivo de este estudio fue determinar el efecto del tiempo, temperatura y la adición de enzimas pécticas en las concentraciones de metanol y acetaldehído durante el proceso de vinificación. Se utilizaron temperaturas $(20,30$ y $\left.35^{\circ} \mathrm{C}\right)$ y tres concentraciones de enzimas pécticas $(0,9$ y 18 $\mu \mathrm{L} / \mathrm{Kg}$ ), dejando que la fermentación se detuviera por el agotamiento del azúcar. Tanto el metanol como el acetaldehído fueron cuantificados durante el proceso de fermentación. La temperatura redujo la producción del metanol, observándose la concentración más baja $(53.543 \pm 3.267$ mg/100 mL de vino) a los $35^{\circ} \mathrm{C}$ en la ausencia de enzimas pécticas. El

*Autor para correspondencia: Carmen María López Saiz

Correo electrónico: carmen.lopezsaiz@unison.mx

Recibido: 2 de febrero de 2021

Aceptado: 2 de junio de 2021 acetaldehído no se ve afectado por las variables. Se ajustaron el alcohol, metanol y acetaldehído a modelación matemática con altos valores de correlación.

Palabras clave. Compuestos tóxicos, vino, modelación matemática, fermentación.

\section{INTRODUCTION}

Wine is a worldwide known beverage; in 2019, 258 millions of hectoliters were produced worldwide (OIV, 2019). Wine is the product of grape fermentation by different yeast species, mainly Saccharomyces cerevisiae; in this process, glucose and fructose are transformed mainly into ethanol and carbon dioxide, nevertheless, this is a much more complex process (Moreno-Arribas and Polo, 2009). There are over 500 different compounds that have been reported in wine, most of them are already present in grape, but some are generated during vinification process (Leighton and Urquiaga, 2000). As it is well known, some of these compounds have been associated to human health improvement, but the real effect has been a topic of discussion since these bioactive compounds are consumed along with ethanol (Iriti and Varoni, 2014), moderate consumption of red wine is associated with the reduction of heart disease and prolonged lifespan (Xiang et al., 2014).

On the other hand, there are other substances that in certain quantities may be considered toxic, such as arsenic and heavy metals, which are present in wine by grape contamination (Hu, 2002). Also, mycotoxins such as ochratoxin $A$, are products by fungal contamination, that can be found in wine and has been reported as a possible carcinogen for humans (IARC, 1993).

On the other hand, some toxic compounds that are produced during fermentation such as methanol and acetaldehyde. Methanol is a one-carbon alcohol that, at room temperature, is liquid and uncolored with a soft smell (Cabaroglu, 2005). During wine production, methanol is first found directly bound to pectic substances in grape and, during fermentation, these substances undergo an enzymatic degradation process, leading to the formation of methanol,

Volumen XXIII, Número 3 
whose concentration has been directly associated with the use of pecinesterase, polygalacturonase, and pectinliase enzyme (Andraous et al., 2004). These enzymes are usually applied to enhance color and produce phenolic compounds in wine (Wightman and Wrolstad, 1996). On the other hand, acetaldehyde is also produced by Saccharomyces cerevisiae during fermentation as a by-product during pyruvate glycolytic fermentation (Herrero et al., 2003). Also, even though acetaldehyde is considered as a component of a high quality wine (Romano et al., 1994), the International Agency for Research on Cancer (IARC) has classified it into the $2 B$ category as a probable carcinogenic agent (IARC, 1999). Based on the above, the present research work explore the way these compounds are affected by vinification process variables, an issue that is highly important for the wine industry.

Considering this information, this study aimed to mathematically determine the effect of time, temperature, and pectic enzyme used, on methanol and acetaldehyde production.

\section{MATERIALS AND METHODS Testing species}

Carignane red grape (Vitis vinifera) was obtained from local vineyards in Hermosillo, Sonora, México, and transported to the laboratory. For each experiment, $20 \mathrm{Kg}$-sample of grapes, cleaned and milled in an equipment designed and built specially for the fermentation laboratory were used. A $200 \mathrm{~mL}$-aliquot of grape juice was taken and then prepared with the addition of $0.16 \mathrm{mg}$ of commercial yeast (Saccharomyces cerevisiae) and $0.40 \mathrm{mg}$ sodium phosphate (to a final concentration of $20 \mu \mathrm{g} / \mathrm{Kg}$ ). While grape juice was being prepared, milled grape was treated with pectic enzyme at different concentrations $(0,9$, and $18 \mu \mathrm{L} / \mathrm{Kg})$ in order to enhance the breaking of pectin bondages and the release of juice.

Grape broth and milled grape were combined after $4 \mathrm{~h}$ and stirred for $2 \mathrm{~min}$ to homogenize the mixture. Then, the grape was pressed using a lab-scale designed and built equipment to separate solids from the liquid phase. Juice was then filtered (grape must) and placed on a lab-designed fermenter and set at different temperatures (20,30, and 35 ${ }^{\circ} \mathrm{C}$ ), selected according to the optimum temperature range for the yeast strain. At this time, a sample was taken from each set of treatments in order to carry out all the analysis at $t=0 \mathrm{~min}$.

\section{Fermenter design}

Lab-scale fermenters were designed and built, to have controlled conditions for the vinification process. Three fermenters were built up with stainless steel (recommended material for fermentations according to Vine et al. (2002)), in order to have three replicates for each treatment. Fermenters were $35 \mathrm{~cm}$ tall with $28 \mathrm{~cm}$ of internal diameter. The container lids were adaptable to the fermenters and closed with the aid of screws to simulate a tank. The cover had an electrical stirrer working at $80 \mathrm{rpm}$ when needed. On the cover of the container, a vent was set to allow the expulsion of fermentation gases. An installed thermocouple monitored the fermentation temperature. Fermenters were placed at a room with controlled temperature.

\section{Sugar measurement}

Sugar was measured indirectly with a digital refractometer (HI 96801, Hanna Instruments, USA) (Greer and Weedon, 2013), at $20^{\circ} \mathrm{C}$.

\section{Alcohol volume percentage}

The amount of alcohol was determined calculating the volume of alcohol in $100 \mathrm{~mL}$ of a hydroalcoholic sample. This was accomplished by distilling musts and wines and collecting the alcohols. Once recovered all the alcohol, distilled samples were cooled down to $20^{\circ} \mathrm{C}$ and measured with calibrated alcoholmeters.

\section{Methanol and acetaldehyde analysis by gas chromato- graphy}

Quantification of methanol and acetaldehyde was carried out by gas chromatography using an HP 5890 series II gas chromatographer equipped with a capilar carbowax HP column $\left(0.25 \mathrm{~mm}\right.$ i.d.). A flame ionizing detector, $\mathrm{N}_{2}$ as a carrier gas, and 2-pentanol as internal standard, were used.

Analytical curves for methanol and acetaldehyde were done using external standards, prepared by dilution of a stock solution in tri-distilled water.

Distilled samples were used to determine the concentration of acetaldehyde and methanol, which were calculated according to the standard curve.

\section{Experimental Design}

Data were analyzed using analysis of variance (ANOVA) with Tukey-Kramer and Duncan's multiple comparison test (JMP 5.1). Grape must was subjected to three fermentation temperatures $\left(15,25\right.$, and $\left.35^{\circ} \mathrm{C}\right)$ and three pectic enzyme concentrations were used $(0,9$, and $18 \mu \mathrm{L} / \mathrm{Kg})$.

\section{Statistical analysis}

Data were analyzed using an analysis of variance (ANOVA) with Tukey-Kramer and Duncan's multiple comparison tests (Number Cruncher Statistical Software (NCSS 2000)). Mathematical models were determined with JMP 5.1.

\section{RESULTS AND DISCUSSION}

Data analysis was carried out to describe fermentation behavior through de description of sugar concentration, alcohol production, and acetaldehyde and methanol production throughout the vinification process, as well as to determine how these variables were affected by temperature and pectic enzyme concentration.

\section{Fermentation}

Carignane grape was fermented under three different temperature conditions, as described in the experimental section. Temperature was monitored, and it was kept at 
$20.02 \pm 1.12,30.22 \pm 1.73$ and $35.02 \pm 2.2^{\circ} \mathrm{C}$; as expected, the time of fermentation was temperature dependent, and they lasted 117,42 and $28 \mathrm{~h}$ at 25,30 , and $35^{\circ} \mathrm{C}$, respectively. This variation is attributed to the activity and reproduction of Saccharomyces cerevisiae, whose metabolism is temperature-dependent, having an optimum temperature of $37^{\circ} \mathrm{C}$ (Mesonides et al., 2002).

In order to monitor fermentation variables (alcohol volume (\%), methanol, and acetaldehyde), samples were taken every 12,6 , and $4 \mathrm{~h}$ for 20,30 , and $35^{\circ} \mathrm{C}$, respectively.

\section{Sugar consumption}

The initial amount of fermentable sugar, measured in ${ }^{\circ}$ Brix, was within the range of 17.0 and 17.8 ; which were within the recommended range for wine (Vine et al., 2002). The reduction of fermentable sugar was periodically measured, depending on the temperature. Samples were taken every 6,3 , and $2 \mathrm{~h}$. The mathematical fit of ${ }^{\circ}$ Brix reduction was described with a natural logarithm, using time as the nondependent variable and ${ }^{\circ} \mathrm{Bx}$ as the dependent variable (Table 1); all mathematical fits described fermentation behaviors with high correlation values.

Table 1. Mathematical fits for ${ }^{\circ} \mathrm{Bx}$ reduction in Carignane grape fermentation.

Tabla 1. Ajuste matemático para la reducción de Bx en la fermentación de uva Carignane.

\begin{tabular}{lcc}
\hline Temperature $\left({ }^{\circ} \mathrm{C}\right)$ & Mathematical fit & $\mathbf{R}^{2}$ \\
\hline 20 & ${ }^{\circ} B x=34.06-7.19 \ln (t)$ & 0.9888 \\
30 & ${ }^{\circ} B x=40.59-10.59 \ln (t)$ & 0.9980 \\
35 & ${ }^{\circ} B x=36.15-10.93 \ln (t)$ & 0.9979 \\
\hline
\end{tabular}

Mathematical variables ${ }^{\circ} \mathrm{Bx}$ and $\mathrm{t}$ represent amount of sugar and time $(\mathrm{h})$, respectively. Mathematical fits were calculated with the data obtained from 9 separate fermentations. Mathematical formula and correlation was given by the mathematical program.

\section{Alcohol production}

Alcohol content is expressed as alc/vol, mainly represents the production of ethanol, since this is the alcohol produced in the highest percentage and constitutes the main purpose of fermentation (Delfini and Formica, 2001). Alcohol production was dependent on sugar concentration, oscillating between 8.6 and $9.3 \mathrm{alc} / \mathrm{vol}$; nonetheless, the amount ${ }^{\circ} \mathrm{Bx}$ necessary to increase $1 \%$ the amount of alcohol did not show statistical difference among them (Table 2), showing that this variable is not temperature nor pectic enzyme dependent.

Ideally, for every mol of glucose, 2 moles of ethanol and 2 moles of carbon dioxide are produced; nevertheless, the real amount produced varies (Morales et al., 2015). A mathematical fit for the final production of alcohol according to the ${ }^{\circ} \mathrm{Bx}$ content on grape was calculated with a $\mathrm{R}^{2}$ of 0.990 as follows:

$$
\% A V=-0.0198+0.52^{\circ} B x
$$

Table 2. ${ }^{\circ} \mathrm{Bx}$ necessary to increase $1 \%$ the alc/vol relationship. Tabla 2. ${ }^{\circ}$ Bx necesarios para incrementar en $1 \%$ la relación alc/vol.

\begin{tabular}{lcc}
\hline $\begin{array}{l}\text { Temperature } \\
\left({ }^{\circ} \mathbf{C}\right)\end{array}$ & $\begin{array}{c}\text { Pectic enzyme } \\
(\mu \mathrm{L} / \mathbf{K g})\end{array}$ & ${ }^{\circ} \mathrm{Bx} / \mathrm{alc}$-vol \\
\hline \multirow{3}{*}{20} & 0 & $1.906 \pm 0.012^{\mathrm{a}}$ \\
& 9 & $1.906 \pm 0.012^{\mathrm{a}}$ \\
& 18 & $1.941 \pm 0.012^{\mathrm{a}}$ \\
30 & 0 & $1.918 \pm 0.065^{\mathrm{a}}$ \\
& 9 & $1.896 \pm 0.051^{\mathrm{a}}$ \\
& 18 & $1.945 \pm 0.043^{\mathrm{a}}$ \\
35 & 0 & $1.943 \pm 0.038^{\mathrm{a}}$ \\
& 9 & $1.943 \pm 0.022^{\mathrm{a}}$ \\
\hline
\end{tabular}

Data represents the mean \pm standard deviation out of three independent experiments. Different letters represent statistical difference.

Where:

$\% A V$ is the final concentration of alcohol-volume ${ }^{\circ} \mathrm{B} x$ the amount of Brix in grape

In order to describe the fermentation process, mathematical fits were calculated for every temperature, associating the amount of alcohol produced (alc/vol) to the fermentation time (Table 3).

Table 3. Mathematical fits for alc/vol production in Carignane grape fermentation.

Tabla 3. Ajuste matemático para la producción de alc/vol en la fermentación de uva Carignane.

\begin{tabular}{lcc}
\hline Temperature $\left(^{\circ} \mathrm{C}\right)$ & Mathematical fit & $\mathbf{R}^{\mathbf{2}}$ \\
\hline 20 & $A V_{20}=3.2 \times 10^{-3}+0.16 \mathrm{t}-7.0 \times 10^{-3} \mathrm{t}^{2}$ & 0.9888 \\
30 & $A V_{20}=2.9 \times 10^{-3}+0.28 \mathrm{t}-1.3 \times 10^{-3} \mathrm{t}^{2}$ & 0.9980 \\
35 & $A V_{20}=7.8 \times 10^{-3}+0.38 \mathrm{t}-2.3 \times 10^{-3} \mathrm{t}^{2}$ & 0.9979 \\
\hline
\end{tabular}

Mathematical variables ${ }^{\circ} \mathrm{Bx}$ and $\mathrm{t}$ represent amount of sugar and time $(\mathrm{h})$, respectively. Mathematical fits were calculated with the data obtained from 9 independent fermentations. Mathematical formula and correlation were given by the mathematical program.

\section{Methanol Production}

Methanol production was monitored during fermentation, and data expressed as fermentation progress (\%FP), was calculated with the formula:

$$
\% F P=\left(1-\frac{{ }^{\circ} B x_{0}-{ }^{\circ} B x_{t}}{{ }^{\circ} B x_{o}}\right) \times 100
$$

Where:

\%FP represents fermentation progress

is $B x_{0}$ vthe initial ${ }^{\circ} B$ rix value on grape

is $B x_{t}$ the ${ }^{\circ} B r i x$ value at a given time

This transformation was used as a dependent variable instead of time; this transformation allowed us to compare the amount of methanol at any given fermentation progress since fermentation time was different for each temperature. All fermentation showed an exponential behavior, where the maximum concentration was achieved at the beginning of 
the fermentation and was maintained during the rest of the process. Final methanol concentrations (Figure 1) demonstrate that both, temperature and enzyme concentration, exert an effect on this variable. The lowest concentrations were obtained at $35^{\circ} \mathrm{C}$ with no addition of pectic enzyme, while the highest were at $20^{\circ} \mathrm{C}$; however, no significant differences were observed among methanol concentrations obtained at $30^{\circ} \mathrm{C}$. The effect of enzyme addition is only significant at $35^{\circ} \mathrm{C}$, this might be due to the fact that Saccharomyces cerevisiae exerts its highest activity at $37^{\circ} \mathrm{C}$ (Mesonides et al., 2002) and can produce pectinesterase enzyme. This specific enzyme has a higher optimum temperature than commercial enzymes (Jayani et al., 2005), and this production could be enough to promote an increase in methanol generation.

None of the fermentation processes generated methanol concentrations above the permitted levels established by international regulations (EEC, 2008), which is $200 \mathrm{mg} / 100$ $\mathrm{mL}$; this means that, regarding the amount of methanol, wine consumption (under experimental conditions) would not represent a health risk. These results are in agreement with those reported by Coelho et al., (2015), who fermented different fruits to obtain fruit wines.

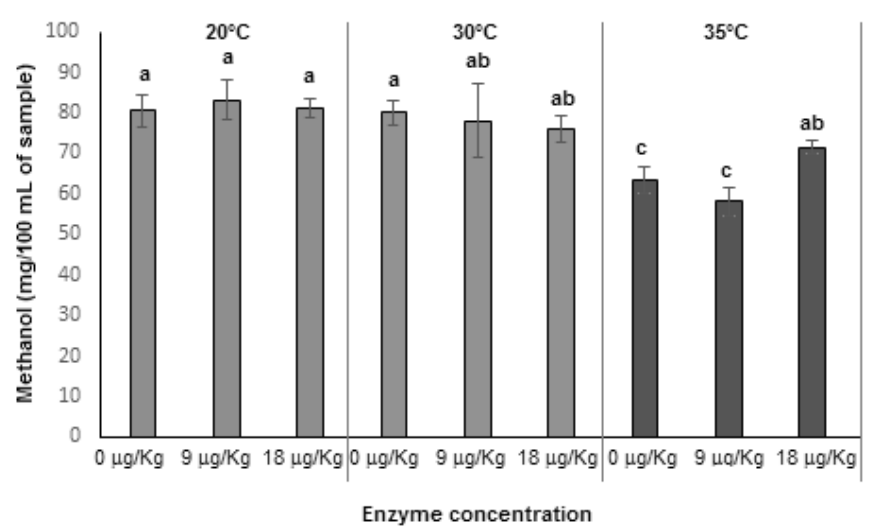

Figure 1. Temperature and pectic enzyme concentration effect on wine methanol concentration. Data represents the mean \pm standard deviation of three independent experiments. Different letters represent statistical difference

Figura 1. Efecto de la temperatura y la concentración de enzimas pécticas en la concentracioón de metanol en vino. Los datos representan la media \pm desviación estándar de tres experimentos independientes. Diferentes letras representan diferencia significativa.

\section{Acetaldehyde production}

Acetaldehyde was also monitored along the fermentation process. The final acetaldehyde concentration was not temperature, nor enzyme concentration dependent (Table 4). This compound might be formed in wine by two different processes; the first one is glycolysis performed by Saccharomyces cerevisiae (Romano et al., 1994), the other one is through oxidation of ethanol when this interacts with phenolic compounds and oxygen (Saucier et al., 1997). Even though acetaldehyde final concentration achieved in this study does not represent a hazard for human health (since national and international legislation establish the higher limit for acetaldehyde at $40 \mathrm{mg} / 100 \mathrm{~mL}$ of wine), the acetal- able 4. Temperature and pectic enzyme concentration effect on wine methanol concentration.

Tabla 4. Efecto de la temperatura y concentración de ezimas pécticas en la concentración de metanol en el vino.

\begin{tabular}{lcc}
\hline Temperature $\left({ }^{\circ} \mathrm{C}\right)$ & $\begin{array}{c}\text { Enzyme concentration } \\
(\mu \mathrm{L} / \mathrm{Kg} \text { of grape })\end{array}$ & $\begin{array}{c}\text { Methanol } \\
(\mathbf{m g} / \mathbf{1 0 0} \mathbf{m L} \text { of wine })\end{array}$ \\
\hline \multirow{3}{*}{20} & 0 & $6.02 \pm 2.35^{\mathrm{a}}$ \\
& 9 & $3.67 \pm 2.79^{\mathrm{a}}$ \\
& 18 & $5.63 \pm 1.35^{\mathrm{a}}$ \\
30 & 0 & $5.52 \pm 2.11^{\mathrm{a}}$ \\
& 9 & $4.11 \pm 1.78^{\mathrm{a}}$ \\
35 & 18 & $6.34 \pm 0.52^{\mathrm{a}}$ \\
& 0 & $6.42 \pm 2.66^{\mathrm{a}}$ \\
& 9 & $4.77 \pm 2.01^{\mathrm{a}}$ \\
& 18 & $6.41 \pm 1.37^{\mathrm{a}}$ \\
\hline
\end{tabular}

Data represents the mean \pm standard deviation of three separate experiments. Different letters represent statistical difference

dehyde concentration through experimental fermentation process was $35 \mathrm{mg} / 100 \mathrm{~mL}$ at $35^{\circ} \mathrm{C}$.

This high acetaldehyde concentration may be due to enzyme activity of Saccharomyces cerevisiae, which shows its highest activity at $37^{\circ} \mathrm{C}$ (Mesonides et al., 2002). Therefore, acetaldehyde production behavior was shown to be time dependent, and it can be described in a plot, starting at 0 $\mathrm{mg} / 100 \mathrm{~mL}$. It achieves the highest concentration at the middle of the fermentation process, and then decreasing to low concentrations; this phenomena might be due acetaldehyde evaporation, which has a boiling point of $21^{\circ} \mathrm{C}$ (Figure 2) (Mauer and Welle, 2008).
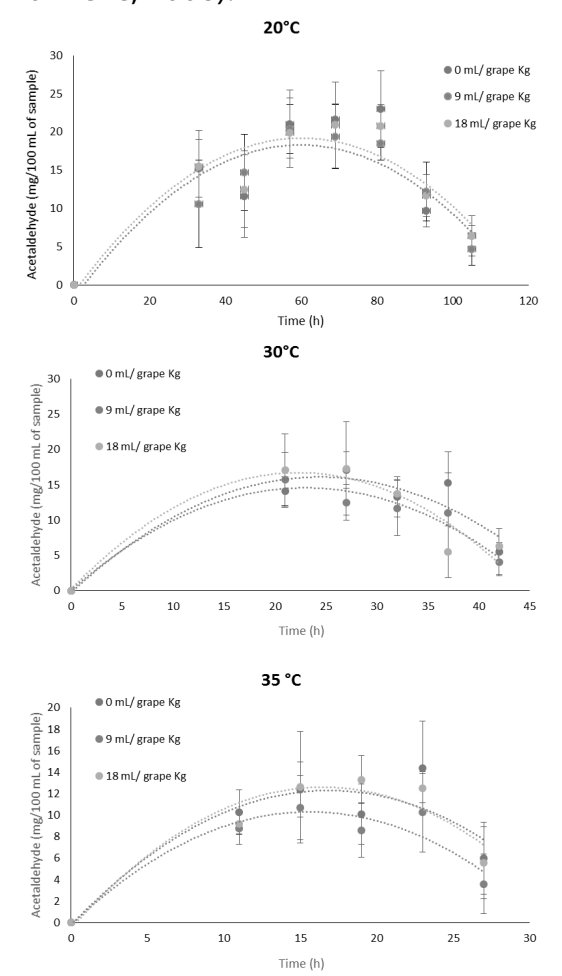

Figure 2. Acetaldehyde concentration through vinification process influenced by temperature and pectic enzyme concentration. Figura 2. Concentración de acetaldehído durante el proceso de vinificación influenciado por temperatura y concentración de enzimas pécticas. 
The behavior of the production of both, methanol and acetaldehyde, during the experimental fermentation processes can be mathematically described (Table 5), where methanol production can be obtained with an exponential equation, with fermentation percentage as the independent variable and methanol concentration measured, as $\mathrm{mg} / 100$ $\mathrm{mL}$ of sample, as the independent variable. On the other hand, acetaldehyde follows a quadratic behavior where the independent variable is time and the dependent variable is acetaldehyde concentration measured in $\mathrm{mg} / 100 \mathrm{~mL}$ of sample.

Table 5. Mathematical fit to describe the production of acetaldehyde and methanol compounds on vinification process.

Tabla 5. Ajuste matemático para describer la producción de acetaldehído y metanol en el proceso de vinificación.

\begin{tabular}{cccccc}
\hline $\begin{array}{l}\text { Temp. } \\
\left({ }^{\circ} \mathbf{C}\right)\end{array}$ & $\begin{array}{c}\text { Enzyme } \\
(\mu \mathbf{L} / \mathbf{K g})\end{array}$ & Acetaldehyde & $\mathbf{R}^{2}$ & Methanol & $\mathbf{R}^{2}$ \\
\hline \multirow{3}{*}{20} & 0 & $A c=1.18+1.06 \mathrm{t}-0.009 t^{2}$ & 0.817 & $M e t=24.24\left(1-\mathrm{e}^{-0.062 F}\right)$ & 0.9851 \\
& 9 & $A c=-0.03+1.03 \mathrm{t}-0.009 t^{2}$ & 0.9918 & $M e t=26.13\left(1-\mathrm{e}^{-0.039 F}\right)$ & 0.9583 \\
& 18 & $A c=1.18+0.96 \mathrm{t}-0.008 t^{2}$ & 0.867 & $M e t=25.92\left(1-\mathrm{e}^{-0.062 F}\right)$ & 0.9931 \\
30 & 0 & $A c=0.34+2.25 \mathrm{t}-0.005 t^{2}$ & 0.7621 & $M e t=25.16\left(1-\mathrm{e}^{-0.037 F}\right)$ & 0.9988 \\
& 9 & $A c=0.75+2.33 \mathrm{t}-0.05 t^{2}$ & 0.8314 & $M e t=24.46\left(1-\mathrm{e}^{-0.046 F}\right)$ & 0.9907 \\
& 18 & $A c=0.68+2.43 \mathrm{t}-0.05 t^{2}$ & 0.9299 & $M e t=24.12\left(1-\mathrm{e}^{-0.062 F}\right)$ & 0.9997 \\
35 & 0 & $A c=0.34+2.25 \mathrm{t}-0.05 t^{2}$ & 0.8619 & $M e t=18.59\left(1-\mathrm{e}^{-0.064 F}\right)$ & 0.9878 \\
& 9 & $A c=0.75+2.33 \mathrm{t}-0.05 t^{2}$ & 0.8475 & $M e t=19.05\left(1-\mathrm{e}^{-0.067 F}\right)$ & 0.9997 \\
& 18 & $A c=0.68+2.43 \mathrm{t}-0.05 t^{2}$ & 0.9290 & $M e t=21.44\left(1-\mathrm{e}^{-0.062 F}\right)$ & 0.9954 \\
\hline
\end{tabular}

\section{CONCLUSIONS}

In this research, under experimental fermentation conditions, the achieved concentration for both compounds is below the recommended levels for wine. Methanol concentration is time, temperature, and enzyme dependent, while acetaldehyde depends only on time. The fermentable sugars reduction and the alcohol, methanol, and acetaldehyde production, can be described through mathematical models with a high correlation coefficient, and even though sugar depletion and alcohol production have been mathematically described before, to our knowledge, there are no previous methanol and acetaldehyde mathematical modeling approaches reported.

\section{AKNOWLEDGEMENTS}

The authors wish to acknowledge the National Council for Science and Technology (CONACyT) of México for graduated scholarship granted to Carmen-María López-Saiz and María-Esther Parra-Durazo. The authors would also like to thank Industrias Vinícolas Pedro Domecq for the financial support and especially to Dr. Rafael Ayala and Juan Pablo Villegas for their technical support.

\section{REFERENCES}

Andraous, J. I., Claus, M. J., Lindemann, D. J., Berglund, K. A. 2004. Effect of liquefaction enzymes on methanol concentration of distilled fruit spirits. American Journal of Enology and Viticulture, 55(2), 199-205.

Cabaroglu, T. 2005. Methanol contents of Turkish varietal wines and effect of processing. Food Control, 16, 177-178.

Coelho, E., Vilanova, M., Genisheva, Z., Oliveira, J. M., Teixeira, J. A., Domingues, L. 2015. Systematic approach for the development of fruit wines from industrially processed fruit concentrates, includying optimization of fermentation parameters, chemical characterization and sensory evaluation. LWT - Food Science and Technology, 62, 10431052.

Delfini, C., Formica, J. 2001. Wine microbiology: science and technology. Italia: L'artistica savigliano.

Regulation (EC) No 110/2008 of the Euopean Parlament and the Council, [Consultada el XX de 2008] 2008. Disponible en: http://data.europa.eu/eli/reg/2008/110(1)/oj.

Greer, D. H.,Weedon, M. M. 2013. The impact of high temperatures on Vitis vinifera cv. Semillon gravepine performance and berry ripening. Frontiers in Plant Science, 4, 1-3.

Herrero, M., García, L. A., Díaz, M. 2003. The effect of $\mathrm{SO}_{2}$ on the production of ethanol, acetaldehyde, organic acids, and flavor volatiles during industrial cider fermentation. Journal of Agricultural and Food Chemistry, 51, 3455-3459.

$\mathrm{Hu}, \mathrm{H} .2002$. Human health and heavy metal exposure. USA: MIT Press.

IARC. 1993. Ochratoxin A IARC monographs on the evaluation of carcinogenic risks to Humans (Vol. 56, pp. 489-521): IARC.

IARC. 1999. Acetaldehyde IARC Monographs on the evaluation of carcinogenic risks to human (Vol. 71, pp. 319): IARC.

Iriti, M., Varoni, E. 2014. Cardioprotective effects of moderate red wine consumption: Polyphenols vs. ethanol. Journal of Applied Biomedicine, 12(4), 193-202. doi:10.1016/j. jab.2014.09.003

Jayani, R., Saxena, S., Gupta, R. 2005. Microbial pectinolytic enzymes: A review. Process Biochemistry, 40, 2931-2944.

Leighton, F., Urquiaga, I. 2000. Polifenoles del vino y salud humana. Antioxidantes y Calidad humana, 7, 5-13.

Mauer, A., Welle, F. 2008. Investigation of the acetaldehyde content of PET raw materials, PET preforms and PET bottles. Prague: Institut Verfahrenstechnik und Verpackung.

Mesonides, F., Schuurmans, J., Joost, M., Hellingwerf, K., Brul, S. 2002. The metabolic response of Saccharomyces cerevisiae to continuous heat stress. Molecular Biology Reports, 29(1-2), 103-106.

Morales, P., Rojas, V., Quirós, M., González, R. 2015. The impact of oxygen on the final alcohol content of wine fermented by a mixed starter culture. Applied Microbial and Cell Physiology, 99, 3993-4003.

Moreno-Arribas, V., Polo, C. 2009. Wine Chemistry and Biochemistry. USA: Springer.

OIV. 2019.2020Wine Production OIV first estimates. International Organisation of Vine and Wine.

Romano, P., Suzzi, G., Turbanti, L., Polsinelli, M. 1994. Acetaldehyde production in Saccharomyces cerevisiae wine yeasts. FEMS Microbiology Letters, 118, 213-218.

Saucier, C., Bourgeois, G., Vitro, C., Roux, D., Glories, Y. 1997. Characterization of (+)-catechin-acetaldehyde polymers: a model for colloidal state of wine polyphenols. Journal of Agricultural and Food Chemistry, 45, 1045-1049.

Vine, R., Harkness, E., Lintora, S. 2002. Winemaking. From grape growing to market place. USA: Kluwer academic/Plenum publishers.

Wightman, J. D., Wrolstad, R. E. 1996. Beta-glucosidase activity in juice-processing enzymes based on anthocyanin analysis. Journal of Food Science, 61, 544-552.

Xiang, L., Xiao, L., Wang, Y., Li, H., Huang, Z., He, X. 2014. Health benefits of wine: Don't expect resveratrol too much. Food Chemistry, 156, 258-263. doi:10.1016/j. foodchem.2014.01.006 